\title{
Alkaline earth stannates applied in photocatalysis: prospection and review of literature
}

\section{(Estanatos de metais alcalinos terrosos aplicados em fotocatálise: prospecção e revisão da literatura)}

\author{
L. M. C. Honorio ${ }^{1}$, M. V. B. Santos ${ }^{2}$, E. C. da Silva Filho ${ }^{2}$, J.A.Osajima ${ }^{2}$, A. S. Maial, I. M. G. dos Santos ${ }^{1 *}$ \\ ${ }^{1}$ Universidade Federal da Paraíba, LACOM, 58059-900, João Pessoa, PB, Brazil \\ ${ }^{2}$ Universidade Federal do Piauí, LIMAV, 64049-550, Teresina, PI, Brazil
}

\begin{abstract}
The $\mathrm{ABO}_{3}$ mixed oxide class known for its perovskite-like structure has aroused great scientific and technological interest in recent decades, due to its optical, magnetic and conductive properties. The objective of this work was to search the articles and patent databases for papers that relate the activity of the alkaline earth metal stannates - $\mathrm{BaSnO}_{3}, \mathrm{CaSnO}_{3}$ and $\mathrm{SrSnO}$ as photocatalysts for environmental application. The databases researched were the Web of Science, Scopus and Scielo for articles and USPTO, EPO and INPI for patent banks. From the exclusion criteria, 21 review articles presented different experimental parameters and conditions. Due to the excellent photocatalytic performance, the stannates presented as promising candidates in the heterogeneous photocatalysis. A description of the main papers published in literature is provided for an overview of the literature data about these materials.
\end{abstract}

Keywords: stannates, perovskite, photocatalysis.

\section{Resumo}

A classe de óxidos mistos $\mathrm{ABO}_{3}$ conhecida por sua estrutura do tipo perovskita vêm despertando grande interesse científicotecnológico nas últimas décadas, em função de suas propriedades ópticas, magnéticas e condutoras. Este trabalho teve por objetivo buscar, nos bancos de artigos e de patentes, trabalhos que relacionem a atividade fotocatalítica dos estanatos de metais alcalinos terrosos - $\mathrm{BaSnO}_{3}, \mathrm{CaSnO}_{3}$ e $\mathrm{SrSnO}_{3}$ como fotocatalisadores para aplicação ambiental. Os bancos de dados pesquisados foram $o$ Web of Science, Scopus e Scielo para os artigos e USPTO, EPO e INPI para os bancos de patentes. A partir dos critérios de exclusão, 21 artigos de revisão apresentaram parâmetros e condições experimentais distintas. Devido ao excelente desempenho fotocatalítico, os estanatos apresentam-se como candidatos promissores na fotocatálise heterogênea.

Palavras-chave: estanatos, perovskita, fotocatálise.

\section{INTRODUCTION}

Pollution of water bodies by chemical products due to anthropogenic activities is a critical matter, which has been initiated ecological concerns on water quality and use [1]. Due to the need of corrective actions, the 'Conselho Nacional de Meio Ambiente' (CONAMA), from Brazil, determined conditions, parameters, standards and guidelines to manage effluent discharge in order to guarantee healthy ecosystems [2]. These guidelines associated with concern about environmental problems and public health make the use of ecologically correct technologies imperative [3]. For instance, advanced oxidation processes (AOPs) have arisen a growing interest from the scientific community as it is an effective method for remediation of reduction of environmental impacts [3-6]. AOPs are based on the formation of highly reactive oxidative compounds, as ozone

*ieda@quimica.ufpb.br
$\left(\mathrm{O}_{3}\right)$, hydrogen peroxide $\left(\mathrm{H}_{2} \mathrm{O}_{2}\right)$ and hydroxyl radicals $\left({ }^{\circ} \mathrm{OH}\right)$ in particular, which promote a fast degradation of organic pollutants being to mineralize them into carbonic gas $\left(\mathrm{CO}_{2}\right)$, water and inorganic ions $\left(\mathrm{SO}_{4}^{2-}, \mathrm{NO}_{3}^{-}, \mathrm{Cl}^{-}\right)[7,8]$. Among AOPs, heterogeneous photocatalysis is an active technology for environmental remediation $[9,10]$.

Synthesis and characterization of semiconductor materials is a well-known research area in science and technology while the search for high-performance heterogeneous photocatalysts is one of these research areas. Recently, alkaline earth stannates with perovskite structure have been highlighted in the technological area due to applications as capacitors [11], solar cells [12], humidity and gas sensors [13], lithium batteries [14], and recently also as photocatalysts $[15,16]$. In relation to photocatalysis, published papers focus on water splitting for hydrogen production and degradation of different organic compounds. Development of researches on tin-based materials is especially important for Brazil, which is the $4^{\text {th }}$ world mine producer ( $8.6 \%$ of the total mine production) and has $14.6 \%$ 
of the tin world reserves, the $3^{\text {rd }}$ biggest one [17]. In spite of the high technological interest in the use of stannates, the amount of published papers on their photocatalytic activity is much smaller than titanate ones. For this reason, this paper aimed at presenting a review about these stannates in order to verify the number of scientific papers published and patents deposited in order to gather information on this application as well as its limitations in order to indicate new research possibilities.

\section{PAPER PROSPECTION AND PUBLISHING}

Methodology: research was done until January 2018, using the scientific databases - Web of Science, Scopus and Scielo; and patent databases: European Patent Office (EPO), United States Patent and Trademark Office (USPTO) and Instituto Nacional de Propriedade Industrial (INPI), from Brazil. The search was done using the following keywords: stannates or $\mathrm{MSnO}_{3}$; barium stannate or $\mathrm{BaSnO}_{3}$; calcium stannate or $\mathrm{CaSnO}_{3}$; strontium stannate or $\mathrm{SrSnO}_{3}$; "photocatalytic properties"; $\mathrm{BaSnO}_{3}$ and photocatalytic; $\mathrm{CaSnO}_{3}$ and photocatalytic; $\mathrm{SrSnO}_{3}$ and photocatalytic. Compound words, as "photocatalytic properties", were placed in quotes in the search field for a correct search, while the booleans 'and/or' were also used. Search was done considering the field tags abstracts, keywords and titles, in the advanced search area. Papers published in 2018 were not included in the review. Due to the diversity of papers found during the search, some exclusion criteria were used to restrict the search, in order to limit it to papers directly related to photocatalysis. For the search in the patent database, only five of the keywords previously described were used. Definition of the keywords was done in agreement to the Law $\mathrm{N}^{\circ} 9279$ relative to the industrial property, which excludes actions, creations, abstract ideas, intellectual activity, methods or inventions which may not be industrialized from protection as invention and utility model [18]. According to this concept, properties do not fit in the patent scope, as they are related to properties and/ or applications relative to the use of some compounds. Due to the absence of the keywords "photocatalytic properties", the expressions related to photocatalysis were not used because they are related to the material characteristic, being necessary to evaluate the objective of the patent in relation to the analyzed compounds. Data processing was based on the title and/or abstract for the EPO database and in the abstract for the USPTO and INPI database.

Published papers: the use of more general keywords as stannates or $\mathrm{MSnO}_{3}$ and photocatalytic properties lead to a bigger amount of publications, while the combined keywords $\left(\mathrm{BaSnO}_{3}\right.$ and photocatalytic; $\mathrm{CaSnO}_{3}$ and photocatalytic; $\mathrm{SrSnO}_{3}$ and photocatalytic) permitted the refinement of the search, with a meaningful smaller amount of papers, especially for the Scielo database (Table I). A closer look to this table and an evaluation of the publication date of the papers showed that research on alkaline earth stannates is relatively recent in relation to photocatalytic properties, as publications between 2007 and 2017 corresponded to 100\% of the papers. According to the Web of Science database, in spite of the highest amount of publications on $\mathrm{BaSnO}_{3}(60 \%$ of the papers published about stannates), a relatively smaller amount of papers was published on photocatalysis (only $3 \%$ ), while these percentages increase to 10 and $12 \%$ for $\mathrm{CaSnO}_{3}$ and $\mathrm{SrSnO}_{3}$, respectively. Moreover, less than $1 \%$ of the papers published about photocatalysis are related to stannates. This analysis indicated that photocatalysis is not a highly explored property for the stannates with perovskite structure. The number of papers published with the combined keywords $\left(\mathrm{BaSnO}_{3}\right.$ and photocatalytic; $\mathrm{CaSnO}_{3}$ and photocatalytic; $\mathrm{SrSnO}_{3}$ and photocatalytic) was 51,4 and 2 for Web of Science, Scopus and Scielo, respectively. From these 57 papers, 20 were repeated. The papers were classified in agreement to their profiles and objectives and, according to their applications, these papers were divided as: $\mathrm{H}_{2}$ generation (9 papers); dye photodegradation (12 papers); and without direct relation to photocatalysis (16 papers), which were nominated as secondary papers. Considering the 21 papers strictly related to photocatalysis, $\mathrm{SrSnO}_{3}$ is the most studied stannate. The secondary papers are currently related to structural modifications (use of dopants, surfactants, etc.),

Table I - Number of articles found on the Web of Science, Scopus and Scielo databases.

[Tabela I - Números de artigos encontrados nos bancos de dados Web of Science, Scopus e Scielo.]

\begin{tabular}{ccccccc}
\hline \multirow{2}{*}{ Keywords } & \multicolumn{2}{c}{ Web of Science } & \multicolumn{2}{c}{ Scopus } & \multicolumn{2}{c}{ Scielo } \\
& Total & $2007-2017$ & Total & $2007-2017$ & Total & 2007-2017 \\
\hline Stannates or $\mathrm{MSnO}_{3}$ & 263 & 153 & 332 & 216 & 5 & 3 \\
Barium stannate or $\mathrm{BaSnO}_{3}$ & 559 & 388 & 247 & 169 & 1 & 0 \\
Calcium stannate or $\mathrm{CaSnO}_{3}$ & 172 & 121 & 68 & 43 & 1 & 0 \\
Strontium stannate or $\mathrm{SrSnO}_{3}$ & 177 & 119 & 72 & 48 & 3 & 3 \\
Photocatalytic properties $_{\mathrm{BaSnO}_{3} \text { and photocatalytic }}^{6931}$ & 18 & 6396 & 6866 & 6306 & 11 & 11 \\
$\mathrm{CaSnO}_{3}$ and photocatalytic & 11 & 11 & 1 & 1 & 1 & 1 \\
$\mathrm{SrSnO}_{3}$ and photocatalytic & 22 & 21 & 1 & 2 & 1 & 1 \\
\hline
\end{tabular}


improvement of the synthesis method, evaluation of the photoluminescent properties, morphological evaluation, and theoretical calculations [19-34].

According to [35], improvements in the photocatalytic efficiency may arise when the process is optimized. For instance, considerable efforts have been done to develop new photocatalysts for water splitting looking forward to understanding the surface reaction mechanism [36]. The behavior of a photocatalytic reaction depends on different factors as the contaminant concentration, presence and concentration of oxidants, light source, operational system (reactor, temperature, $\mathrm{pH}$, etc.) and on the own photocatalyst, which must have potential values of the valence band edge and of the conduction band edge with an adequate energy for electron transfer processes to and from the adsorbate [37]. In relation to the papers about dye photodegradation, the most studied dyes are remazol golden yellow (RNL) and methylene blue (MB), which corresponded to the $60 \%$ of the analyzed papers. RNL is an anionic dye with the azo chromophore group in its composition, characterized by nitrogen-nitrogen

Table II - Summary of the synthesis methods and experimental parameters.

[Tabela II - Resumo dos métodos de síntese e parâmetros experimentais.]

\begin{tabular}{|c|c|c|c|c|c|}
\hline Stannate & Method of synthesis & Precursors & $\mathrm{T}\left({ }^{\circ} \mathrm{C}\right)$ & $\mathrm{t}(\mathrm{h})$ & Ref \\
\hline \multicolumn{6}{|c|}{ Hydrogen production } \\
\hline $\mathrm{SrSnO}_{3}$ & $\begin{array}{l}\text { Sol. chemistry / solid } \\
\text { state }\end{array}$ & $\begin{array}{c}\mathrm{Sr}\left(\mathrm{NO}_{3}\right)_{2} / \mathrm{SnCl}_{4} \mathrm{Sr}\left(\mathrm{NO}_{3}\right)_{2} / \mathrm{H}_{2} \mathrm{O}_{2} / \\
\mathrm{Sr}\left(\mathrm{NO}_{3}\right)_{2} / \mathrm{SnCl}_{4}\end{array}$ & $700-1000$ & $6-6$ & {$[15]$} \\
\hline $\mathrm{MSnO}_{3}$ & Solid state & $\mathrm{MCO}_{3}(\mathrm{M}=\mathrm{Ca}, \mathrm{Sr}, \mathrm{Ba}) \mathrm{SnO}_{2}$ & $1000-1450$ & $6-15$ & {$[36]$} \\
\hline $\mathrm{MSnO}_{3}$ & $\begin{array}{l}\text { Hydrothermal and } \\
\text { calcination }\end{array}$ & $\underset{\mathrm{NaOH}}{\mathrm{CaCl}_{2} / \mathrm{SrCl}_{2} / \mathrm{BaCl}_{2} \cdot 2 \mathrm{H}_{2} \mathrm{O} / \mathrm{SnCl}_{4} /}$ & $180-700$ & $24-6$ & [43] \\
\hline $\mathrm{SrSnO}_{3}$ & $\begin{array}{l}\text { Hydrothermal and } \\
\text { calcination }\end{array}$ & $\mathrm{Sr}\left(\mathrm{NO}_{3}\right)_{2} / \mathrm{Na}_{2} \mathrm{SnO}_{3}$ & $180-1000$ & $16-6$ & {$[44]$} \\
\hline $\mathrm{BaSnO}_{3}$ & Polymer complex & $\begin{array}{l}\mathrm{SnCl}_{4} \cdot 5 \mathrm{H}_{2} \mathrm{O} / \text { ethylene glycol / citric acid / } \\
\qquad \mathrm{BaCO}_{3} / \mathrm{SrCO}_{3}\end{array}$ & 1000 & 3 & {$[45]$} \\
\hline $\mathrm{SrSnO}_{3}$ & Solid state & $\mathrm{Sr}\left(\mathrm{NO}_{3}\right)_{2} / \mathrm{SnO}_{2}$ & - & - & [46] \\
\hline $\mathrm{SrSnO}_{3}$ & Solid state & $\mathrm{SrCO}_{3} / \mathrm{SnO}_{2}$ & 1200 & - & {$[50]$} \\
\hline $\mathrm{BaSnO}_{3}$ & Citrate modified & $\mathrm{Ba}\left(\mathrm{NO}_{3}\right)_{2} / \mathrm{Pb}\left(\mathrm{CH}_{3} \mathrm{CO}_{2}\right)_{4} \mathrm{SnCl}_{4} \cdot 5 \mathrm{H}_{2} \mathrm{O}$ & 700 & 10 & [51] \\
\hline $\mathrm{SrSnO}_{3}$ & $\begin{array}{l}\text { Hydrothermal and } \\
\text { calcination }\end{array}$ & $\mathrm{Sr}\left(\mathrm{CH}_{3} \mathrm{COO}\right)_{2} / \mathrm{SnCl}_{4} \cdot 5 \mathrm{H}_{2} \mathrm{O} / \mathrm{NaOH}$ & 700 & 3 & {$[52]$} \\
\hline \multicolumn{6}{|c|}{ Dye photodegradation } \\
\hline $\mathrm{SrSnO}_{3}$ & $\begin{array}{l}\text { Hydrothermal and } \\
\text { calcination }\end{array}$ & $\mathrm{SnCl}_{2} \cdot 2 \mathrm{H}_{2} \mathrm{O} \mathrm{Sr}\left(\mathrm{CH}_{3} \mathrm{CO}_{2}\right)_{2}$ & $\begin{array}{l}500,700 \\
\quad 900\end{array}$ & 3 & [16] \\
\hline $\mathrm{BaSnO}_{3}$ & Co-precipitation & $\mathrm{Ba}(\mathrm{Sal})_{2} / \mathrm{SnCl}_{2} \cdot 2 \mathrm{H}_{2} \mathrm{O}$ & 700 & 4 & {$[41]$} \\
\hline $\mathrm{BaSnO}_{3}$ & Co-precipitation & $\mathrm{Ba}(\mathrm{Sal})_{2} / \mathrm{SnCl}_{2} \cdot 2 \mathrm{H}_{2} \mathrm{O}$ & 700 & 4 & [42] \\
\hline $\mathrm{SrSnO}_{3}: \mathrm{N}$ & Solid state & $\mathrm{SrCO}_{3} / \mathrm{SnO}_{2}$ & $800-1000$ & $6-24$ & {$[53]$} \\
\hline $\mathrm{Sr}_{1-\mathrm{x}} \mathrm{Ba}_{\mathrm{x}} \mathrm{SnO}_{3}$ & Solid state & $\begin{array}{c}\mathrm{SrCO}_{3}, \mathrm{SnO}_{2}, \mathrm{BaCO}_{3} \mathrm{SrCO}_{3} / \mathrm{SnO}_{2} / \\
\mathrm{Sr}\left(\mathrm{NO}_{3}\right)_{2}\end{array}$ & $1000-1100$ & $6-8$ & {$[54]$} \\
\hline $\mathrm{SrSnO}_{3}$ & Precipitation & $\mathrm{Sr}(\mathrm{sal})_{2} / \mathrm{SnCl}_{2} \cdot 2 \mathrm{H}_{2} \mathrm{O}$ & 900 & 5 & {$[55]$} \\
\hline $\mathrm{MSnO}_{3}$ & $\begin{array}{l}\text { Hydrothermal and } \\
\text { calcination }\end{array}$ & $\mathrm{NaSnO}_{3} / \mathrm{Ca}\left(\mathrm{NO}_{3}\right)_{2} / \mathrm{Sr}\left(\mathrm{NO}_{3}\right)_{2} / \mathrm{Ba}\left(\mathrm{NO}_{3}\right)_{2}$ & 800 & 6 & {$[56]$} \\
\hline $\mathrm{Ag} / \mathrm{SrSnO}_{3}$ & $\begin{array}{l}\text { Hydrothermal and } \\
\text { calcination }\end{array}$ & $\mathrm{Sr}\left(\mathrm{CH}_{3} \mathrm{CO}_{2}\right)_{2} / \mathrm{SnCl}_{2} \cdot 2 \mathrm{H}_{2} \mathrm{O} / \mathrm{AgNO}_{3}$ & 900 & 3 & {$[57]$} \\
\hline $\mathrm{BaSnO}_{3}$ & Modified Pechini & $\begin{array}{c}\text { Sn metal / } \mathrm{Ba}\left(\mathrm{NO}_{3}\right)_{2} \text { citric acid / ethylene } \\
\text { glycol / } \mathrm{NH}_{4} \mathrm{OH}\end{array}$ & 800 & 4 & {$[58]$} \\
\hline $\mathrm{CaSn}(\mathrm{OH})_{6}$ & Sonochemical & $\begin{array}{c}\mathrm{Na}_{2} \mathrm{Sn}(\mathrm{OH})_{6} / \mathrm{SnCl}_{4} .5 \mathrm{H}_{2} \mathrm{O} \mathrm{CaCl} / \mathrm{Na}_{2} \mathrm{CO}_{3} \\
/ \mathrm{NaOH}\end{array}$ & - & - & {$[59]$} \\
\hline $\mathrm{CaSnO}_{3}$ & Modified Pechini & $\begin{array}{c}\text { Metallic } \mathrm{Sn} / \mathrm{Ca}\left(\mathrm{NO}_{3}\right)_{2} \text { citric acid / } \\
\text { ethylene glycol / } \mathrm{NH}_{4} \mathrm{OH}\end{array}$ & 800 & 4 & {$[60]$} \\
\hline $\mathrm{CaSnO}_{3}$ & Co-precipitation & $\mathrm{Ca}(\mathrm{Sal})_{2} / \mathrm{SnCl}_{2}$ & 900 & 5 & {$[61]$} \\
\hline
\end{tabular}


double bonds $(-\mathrm{N}=\mathrm{N}-)$ bonded to aromatic groups. These dyes correspond to $70 \%$ of the total amount of textile dyes used in industry due to their intense varied colors $[1,38]$. Due to their complex structure and chemical stability, azodyes are highly resistant to chemical and photochemical degradation processes, especially the biological treatments, most of them ineffective [1,9]. Other azo-dyes tested in the papers were methyl orange, acid black-1, acid blue-92, acid brown-14, eriochrome black T, brown-14 acid. MB is a cationic dye, with heterocyclic structure and molecular formula $\mathrm{C}_{16} \mathrm{H}_{18} \mathrm{ClN}_{3} \mathrm{~S} . \mathrm{xH}_{2} \mathrm{O}$. Due to its simple molecular structure and well-defined spectrum, MB is highly used as a model dye for evaluation of organic compound photodegradation. Moreover, it is widely used in textile industry and when discarded without previous adequate treatment it contaminates the ecosystems and leading to harmful effects on the environment and for the human being [39, 40]. Another dye whose photodegradation was evaluated using stannates was erythrosine, which is an anionic dye [41]. None of the papers cited in this review evaluated the photodegradation mechanism after the catalytic process, while some simplifications were proposed by some authors [41-43], which indicates the need of monitoring the degradation of the target molecules with the identification of the by-products and/or reaction intermediates, which may be more harmful than the own organic molecule.

In relation to photocatalytic tests for $\mathrm{H}_{2}$ production using stannates, different sacrifice agents have been used, as methanol $\left(\mathrm{CH}_{4} \mathrm{O}\right)$ and ethanol $\left(\mathrm{C}_{2} \mathrm{H}_{6} \mathrm{O}\right)$, with or without cocatalysts, as $\mathrm{Pt}, \mathrm{RuO}_{2}, \mathrm{NiOx}$ and $\mathrm{AgNO}_{3}$ [44-46]. Among the different co-catalysts, $\mathrm{Pt}$ has been widely used for different materials, consisting of an excellent alternative to improve the electron trapping on the semiconductor surface making $\mathrm{H}_{2}$ production easier, as observed by Xing et al. [47], who deposited $\mathrm{Pt}$ on $\mathrm{TiO}_{2}$. Since then, the photocatalytic production of $\mathrm{H}_{2}$ by the direct $\mathrm{H}_{2} \mathrm{O}$ photodecomposition has been attracting increasing attention due to the possibility of decreasing environmental contamination and energy exhaustion. In relation to stannates, their properties seem to join thermodynamic and kinetic factors, which satisfy conditions of $\mathrm{H}_{2}$ production using photocatalysis [43]. Analysis of the papers published about alkaline earth stannates indicated the use of different synthesis methods [20]. Different properties can be observed depending on the use of solid-state reaction (the so-called ceramic method of oxide mixture) or chemical methods, as sol-gel, co-precipitation, Pechini, hydrothermal. The method not only influences the presence of secondary or intermediate phases, but also determines the morphology, surface area, particle size distribution and crystallinity $[48,49]$. Table II summarizes the methods used in these syntheses, precursors, calcination temperature and time for different stannates. The most used method for synthesis of stannates with perovskite structure is the hydrothermal one. This is a promising method, already used in the synthesis of different crystalline metal oxides, with high homogeneity, high purity and well-defined morphologies. During synthesis, a fast heating to the desired temperature is used, which is usually low even when compared to most chemical methods. The heat treatment time depends a lot on the heating method; conventional heating usually requires long periods of synthesis while hydrothermal heating leads to a fast crystallization $[16,62,63]$. In relation to stannates, after hydrothermal synthesis, a post heat treatment is done at temperatures above $500{ }^{\circ} \mathrm{C}$ due to the formation of a stable hydroxide phase, which must be dehydrated in order to obtain the desired oxide.

Deposited patents: results of the search realized using the EPO, USPTO and INPI databases are presented in Table III, which shows a considerable number of patents deposited for the used expressions, especially in the European database. On the other hand, the INPI database did not show any results using keywords in English or Portuguese, which indicated that these materials were not widely explored in the country. As already pointed out, Brazil is one of the world largest producers of cassiterite, $\mathrm{SnO}_{2}$, used for the synthesis of stannates by solid-state reaction and researches about stannates with perovskite structure can bring an important contribution for the national development. As the keywords "strontium stannate" or $\mathrm{SrSnO}_{3}$ presented the highest amount of publications in photocatalysis, patents found for this material were more carefully evaluated. One patent was deposited on both EPO and USPTO databases. Innovations about $\mathrm{SrSnO}_{3}$ concern the structural, textural and morphological modifications of the compounds. None of the patents indicated the use of $\mathrm{SrSnO}_{3}$ as photocatalyst and most applications were related to luminescent of electrical properties. Patent deposits are directly related to the development of new synthesis procedures or new applications. Moreover, inventions are related to different forms (films, mesoporous materials,

Table III - Numbers of patents found in the EPO, USPTO and INPI patents database.

[Tabela III - Quantidade de patentes encontradas nos bancos de patentes EPO, USPTO e INPI.]

\begin{tabular}{cccccc}
\hline Keywords & USPTO & EPO & $\begin{array}{c}\text { INPI } \\
\text { (English) }\end{array}$ & $\begin{array}{c}\text { INPI } \\
\text { (Portuguese) }\end{array}$ & $\begin{array}{c}\text { INPI } \\
\text { (Portuguese) }\end{array}$ \\
\hline Stannates or $\mathrm{MSnO}_{3}$ & 21 & 172 & 0 & Estanatos ou $\mathrm{MSnO}_{3}$ & 0 \\
Barium stannate or $\mathrm{BaSnO}_{3}$ & 5 & 167 & 0 & Estanato de bário ou $\mathrm{BaSnO}_{3}$ & 0 \\
Calcium stannate or $\mathrm{CaSnO}_{3}$ & 2 & 91 & 0 & Estanato de cálcio ou $\mathrm{CaSnO}_{3}$ & 0 \\
Strontium stannate or $\mathrm{SrSnO}_{3}$ & 1 & 32 & 0 & Estanato de estrôncio ou $\mathrm{SrSnO}_{3}$ & 0 \\
\hline
\end{tabular}


etc.) or to a high performance in different applications in industrial and technological areas (as photoluminescence, piezoelectricity, conductivity, electroluminescence, high dielectric constant, light emission devices). For this reason, the absence or the low number of patents about stannates can be directly related to the number of publications. Otherwise, it may indicate the lack of partnerships among research centers and industries, especially considering the promising properties already reported for these stannates.

\section{LITERATURE REVIEW}

Perovskites: are usually oxides with $\mathrm{ABX}_{3}$ stoichiometry, where: A are cations with big ionic radii as alkaline metals, alkaline earth metals and rare earths occupying dodecahedral sites; B are cations with smaller ionic radii, usually $3 \mathrm{~d}, 4 \mathrm{~d}$ and $5 \mathrm{~d}$ transition metals in octahedral coordination; $\mathrm{X}$ is an anion, usually $\mathrm{O}^{2-}$, under octahedral coordination, constituting the perovskite oxide structure, $\mathrm{ABO}_{3}$ [64-66]. The ideal perovskite structure has a cubic unit cell, with A cations in the corner of the cube in a 12-fold coordination, B cation in the center of the cube with oxygen anions around it, placed in the center of each cube face, forming the $\mathrm{BO}_{6}$ octahedra, as displayed in Fig. 1 [64]. Alkaline earth stannates have Sn(IV) occupying the $\mathrm{B}$ sites while alkaline earth cations occupy A cation in the $\mathrm{ABO}_{3}$ structure [56] comprising the three compounds: barium stannate $\left(\mathrm{BaSnO}_{3}\right)$, strontium stannate $\left(\mathrm{SrSnO}_{3}\right)$, and calcium stannate $\left(\mathrm{CaSnO}_{3}\right)$. The first one has a cubic space group $(\mathrm{Pm} 3 \mathrm{~m})$, while the other two have an orthorhombic space group (Pbnm) [54]. As the A cation size increases $\left(\mathrm{Ca}^{2+}<\mathrm{Sr}^{2+}<\mathrm{Ba}^{2+}\right)$, tilting among $\mathrm{SnO}_{6}$ octahedra decreases and the Sn-O-Sn angle approaches $90^{\circ}$, with a more symmetric structure $[36,56,67,68]$. Octahedron distortions have an important role in the migration of photogenerated charge carrier, which is directly related to the photocatalytic efficiency $[15,36,56]$. According to [46], the presence of charge carriers in $\mathrm{SrSnO}_{3}$ favor the reduction of $\mathrm{O}_{2}$ molecules adsorbed on the powder surface with an increase in the formation of reducing species $\left(\mathrm{O}_{2}^{-}, \mathrm{HO}_{2}^{\circ}, \mathrm{OH}^{-}\right)$and a higher photocatalytic efficiency. Stannates have been receiving considerable attention due to their electronic, refractory, dielectric photoluminescent, catalytic and photocatalytic properties providing wide technological applications $[20,69] . \mathrm{BaSnO}_{3}$ is an ideal cubic perovskite which, in the presence of defects in the structure, becomes an n-type semiconductor with a band gap in the range of $3.1 \mathrm{eV}$; it is suitable for use as photocatalysts [20]. $\mathrm{CaSnO}_{3}$ is an excellent semiconductor with dielectric characteristics, offering a wide field of technological applications [70, 71]. $\mathrm{SrSnO}_{3}$ is characterized by distorted cubes in which coordination around $\mathrm{Sn}^{4+}$ does not change, as does the three-dimensional arrangement of the octahedrons [72]. According to the literature [72, 73], $\mathrm{SrSnO}_{3}$ undergoes phase transitions, changing from orthorhombic to tetragonal and from tetragonal to cubic, with increasing temperature and/or use of dopants. a)

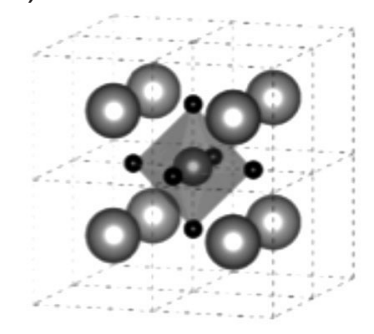

b)
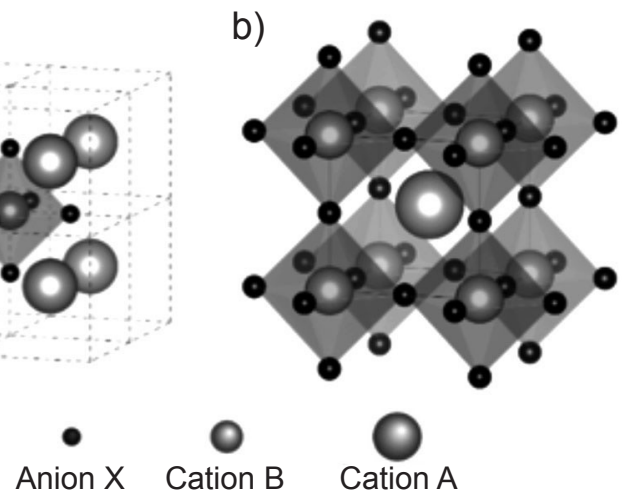

Figure 1: Schematic representation of perovskite structure: a) cation B at octahedral site; and b) cation A at dodecahedral site; adapted from [64], ICSD-239582.

[Figura 1: Representação esquemática da estrutura perovskita: a) cátion B em sítio octaédrico; e b) cátion A em sítio dodecaédrico; adaptado de [64], ICSD-239582.]

Photocatalysis: heterogeneous photocatalysis is a technology able to solve energetic and environmental issues. It comprises a photoinduction process, which takes place on a semiconductor surface under UV or visible light irradiation $[74,75]$. When the photon energy $(\mathrm{hv})$ is equal or higher than the band gap energy, electrons are excited from the valence band (VB) to the conduction band (CB) originating a photogenerated electron/hole pair $\left(\mathrm{e}_{\mathrm{cb}}{ }^{-} / \mathrm{h}_{\mathrm{vb}}{ }^{+}\right)$, as shown in Fig. 2. When these pairs undergo a direct or indirect recombination due to surface traps, by radiative or non-radiative processes, chemical reactions do not take place, while charge migration to the semiconductor surface may induce oxidation and/or reduction reactions [7678]. The redox reactions may occur by direct or indirect mechanisms: in the direct one, charge transfer occurs from the photocatalyst to the target molecule (as a pollutant for example) adsorbed on the surface; in the indirect mechanism, other molecules undergo oxidation or reduction reactions with the formation of radicals $\left({ }^{\circ} \mathrm{O}_{2}^{-}, \mathrm{H}_{2} \mathrm{O}_{2}\right.$ and $\left.{ }^{\circ} \mathrm{OH}\right)$, which may react with the target molecule [79-81]. Recently, Mudring et al. [25] evaluated the catalytic activity of $\mathrm{Sr}_{1-\mathrm{x}} \mathrm{Ba}_{\mathrm{x}} \mathrm{SnO}_{3}$ for the photohydroxilation of terephthalic acid (TA). According to the authors, the sample $\mathrm{Sr}_{0.8} \mathrm{Ba}_{0.2} \mathrm{SnO}_{3}$ had the highest photocatalytic activity due to the enhanced separation of photogenerated charge carrier besides the highest reduction ability, which was directly related to the more negative level of the bottom of the conduction band. Moreover, a synergy among different factor takes place, due to the higher surface area, lattice distortion and small crystallite size. The $\mathrm{SnO}_{6}$ distortion associated to the tilting among octahedra was associated to the improvement of charge separation due to local fields in the interior of distorted octahedra [25], as already pointed out for different indates [82]. Another important factor is the position of the bottom of the conduction band and of the top of the valence band, which must favor the electron transfer from $\mathrm{CB}$ to the adsorbed molecule or from the adsorbed molecule to the VB [83]. Unfortunately, there are few experimental data on the values of these 


\section{CB}

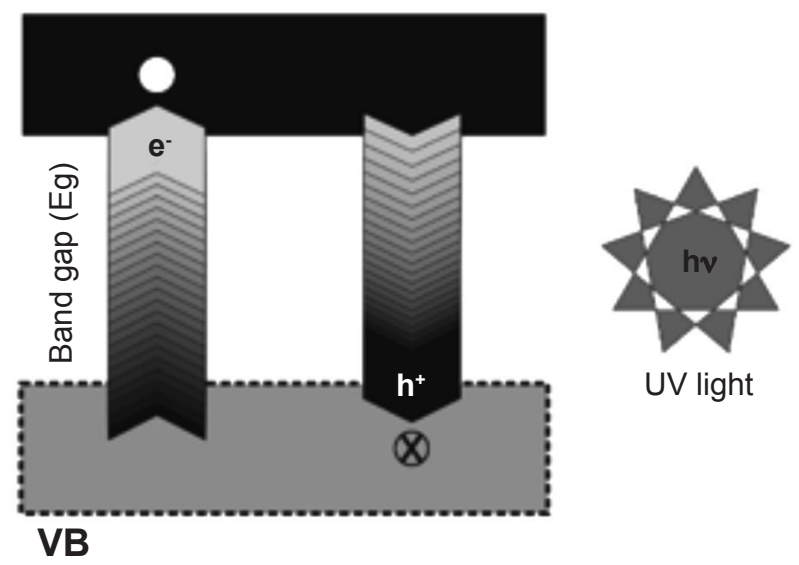

Figure 2: Bands diagram of a semiconductor with formation of holes $\left(\mathrm{h}^{+}\right)$and electrons (e $\left.\mathrm{e}^{-}\right)$after UV irradiation; adapted from [78]. [Figura 2: Diagrama de bandas de um semicondutor com formação de buracos $\left(h^{+}\right)$e elétrons $\left(e^{-}\right)$após irradiação UV; adaptado de [78].]

energies for stannates and only $\mathrm{BaSnO}_{3}$ was experimentally studied [84]. For $\mathrm{SrSnO}_{3}$ and $\mathrm{BaSnO}_{3}$, theoretical data were calculated in [25] from electronegativity data and confirmed the possibility of the electron transfer from the VB to the $\mathrm{CB}$, which enables the formation of hydroxyl radicals [25]. The $\mathrm{Sr}_{x} \mathrm{Ba}_{1-\mathrm{x}} \mathrm{SnO}_{3}(\mathrm{x}=0.0,0.2,0.4,0.6,0.8,1.0)$ solid solution was studied in [85] using the crystallographic data presented in [68], using the density functional theory (DFT), approximation local density (LDA) and approximation generalized gradient (GGA). The solid solution composed of $80 \%$ of $\mathrm{Sr}$ has the orthorhombic Pbnm space group, with the tilting of $\mathrm{SnO}_{6}$ octahedra around the c-axis and diagonal tilting parallel to the b-axis. Results indicated a variation of the structural parameters of $\mathrm{ASnO}_{3}$ crystals as a function of the A cation radius, in agreement to the experimental results obtained in [68]. Moreover, Sr replacement by Ba leads to a decrease in the band gap, as shown in [85], which may favor the photocatalytic activity, as observed in [25].

Hydrogen production: as already discussed, stannates with perovskite structure $\left(\mathrm{SrSnO}_{3}, \mathrm{BaSnO}_{3}, \mathrm{CaSnO}_{3}\right)$ have been applied in the photocatalytic splitting of $\mathrm{H}_{2} \mathrm{O}$ and in the $\mathrm{H}_{2}$ production (Table IV). The photocatalytic activity has been associated with the structural defects, oxygen vacancies and material crystallinity, besides other characteristics $[15,36$, $51,56]$. The photocatalytic efficiency of stannates has been studied by different researchers. One of the most interesting papers was published by Zhang et al. [36], who synthesized $\mathrm{ASnO}_{3}(\mathrm{~A}=\mathrm{Ca}, \mathrm{Sr}, \mathrm{Ba})$ stannates with perovskite structure by solid-state reaction and correlated their crystalline structure and the symmetry with the photocatalytic results. The authors evaluated the influence of the A cation in the lattice vibration and in the electronic structure correlating with photophysical and photocatalytic properties. The smallest the A cation, the highest the inclination among octahedra and the symmetry distortion, which can be assigned to the covalent character as $\mathrm{O}^{2-}$ electronic cloud is pulled by the $\mathrm{A}$ cation distorting the lattice. As a consequence, a meaningful change in the A coordination environment is observed, while the coordination around $\mathrm{Sn}^{4+}$ is maintained as well as the tridimensional arrangement of the octahedra. Besides local structure, another consequence of the smallest A cation size is the elevation of the conduction band edge potential and a decrease in the potential of the valence band edge which increases the band gap. In addition, these distortions influence the band widths, which have an impact on the mobility of carriers. All these changes have a meaningful influence on the photocatalytic activity leading to a higher efficiency of $\mathrm{CaSnO}_{3}$ in the $\mathrm{H}_{2}$ production, while $\mathrm{BaSnO}_{3}$ has the lowest activity. The use of $\mathrm{RuO}_{2}$ as co-catalyst improves the efficiency for $\mathrm{SrSnO}_{3}$ and $\mathrm{CaSnO}_{3}$ but has no positive effect for $\mathrm{BaSnO}_{3}$, what may be related to the mobility of the photogenerated charge carriers, associated to the octahedra distortion. Another comparison of the different $\mathrm{ASnO}_{3}$ perovskites was done by Zhong et al. [43], who synthesized materials with different morphologies and evaluated their activities in the photocatalytic production of $\mathrm{H}_{2}$ from an ethanol/water solution. While the rate of $\mathrm{H}_{2}$ evolution was $27.4 \mu \mathrm{mol}^{-1}$ for $\mathrm{CaSnO}_{3}$, only 4.2 and $2.4 \mu \mathrm{mol}^{-1} \mathrm{~h}^{-1}$ were obtained for $\mathrm{SrSnO}_{3}$ and $\mathrm{BaSnO}_{3}$, respectively, indicating that $\mathrm{CaSnO}_{3}$ presented a much higher activity than the other two perovskites. This behavior was related to surface reactions, due to the formation of $\mathrm{CaSn}(\mathrm{OH})_{6}$ during the photocatalytic reaction. The $\mathrm{CaSn}(\mathrm{OH})_{6} / \mathrm{CaSnO}_{3}$ composite improves the separation and the transfer of the photogenerated charges, increasing the hydrogen production. In spite of the highest efficiency of $\mathrm{CaSnO}_{3}$ in the $\mathrm{H}_{2}$ production indicated by both papers, up to our knowledge no other works were published using this material for such application. Otherwise, two other papers evaluated the influence of barium partial replacement in the photocatalytic activity of $\mathrm{BaSnO}_{3}$. For instance, Yupeng et al. [45] confirmed the low photocatalytic activity of $\mathrm{BaSnO}_{3}$, but observed an improvement by $\mathrm{Sr}^{2+}$ replacement, which was assigned to the highest reducing ability of the photogenerated electrons, besides the more favorable migration of the charge carriers. $\mathrm{Pb}^{2+}$ doping was evaluated by Borse et al. [51], who observed a change in the band gap assigned to the formation of defects in the lattice of $\mathrm{BaSnO}_{3}$, which increases the photocatalytic efficiency.

The other five papers displayed in Table IV use $\mathrm{SrSnO}_{3}$ as a photocatalyst. Although doping was not used for this material, different co-catalysts were evaluated [15, 44, 46, $50,52]$. The morphology and the use of nanoparticles were also evaluated in $[15,44,52]$ to improve the surface area and the photocatalytic efficiency. To obtain the nanoparticles, Chen et al. [44] synthesized the $\operatorname{SrSn}(\mathrm{OH})_{6}$ precursor by the conventional hydrothermal method, which was calcined at $1100{ }^{\circ} \mathrm{C}$ to obtain dumbbell-like and rodlike $\mathrm{SrSnO}_{3}$ nanostructures. Pt was used as a co-catalyst for $\mathrm{H}_{2}$ production from the methanol/water solution. The highest efficiency was attained for rodlike morphologies, assigned to its highest surface area. The behavior of the nanostructures was compared to $\mathrm{SrSnO}_{3}$ synthesized by solid-state reaction and showed an activity 10 times higher for $\mathrm{H}_{2}$ and $\mathrm{O}_{2}$ evolution. 
The results indicated that the hydrothermal method produces crystalline materials, with high homogeneity, high purity and well-defined morphology, and is a promising method to synthesize photocatalytic materials with high efficiency. Lee et al. [15] used a chemical solution to synthesize $\mathrm{SrSnO}_{3}$ particles with peanuts morphology, which were compared to particles synthesized by solid-state reaction. Both samples were impregnated with $1 \mathrm{wt} \%$ of $\mathrm{NiO}_{x}$, used as co-catalyst. Similarly to [44], Lee et al. [15] also observed a much higher activity for the nanometric samples, with an activity 12 times higher. The authors correlated the highest activity with the band gap of the material, besides the surface area and the crystallinity. Both works emphasized the use of co-catalysts to attain a high photocatalytic efficiency.

Alammar et al. [52] performed the microwave-assisted synthesis of $\mathrm{SrSnO}_{3}$ by using various ionic liquids (ILs), followed by a thermal treatment to improve the material crystallinity. Besides the $\mathrm{H}_{2}$ evolution, the authors also used the photohydroxylation of terephthalic acid to evaluate the formation of hydroxyl radicals. They evaluated the influence of different ILs on the $\mathrm{SrSnO}_{3}$ morphology and on the photocatalytic activity, confirming the lowest particle agglomeration by the use of ILs during synthesis and the formation of spheres or rodlike particles. Theoretical calculation of the band edge position confirmed the possibility of the electron transfer for the $\mathrm{H}_{2}$ production, as the energy of the bottom of the conduction band is around $-0.9 \mathrm{eV}$, which is more negative than the reduction potential of $\mathrm{H}^{+} / \mathrm{H}_{2}(0 \mathrm{eV})$ and makes $\mathrm{H}_{2}$ generation feasible. This band edge position is also more negative than the reduction potential of the $\mathrm{O}_{2} / \mathrm{O}_{2}{ }^{-}$ $(-0.33 \mathrm{eV})$, which favors the formation of the $\mathrm{OH}$ radicals. The use of $0.025 \mathrm{wt} \%$ of $\mathrm{Rh}$ as co-catalyst improved the $\mathrm{H}_{2}$ production, with a lower efficiency when $0.05 \mathrm{wt} \%$ was used. The high photocatalytic activity was related to the surface area, due to the formation of nanometric crystals and to the band edge position. In a different approach, Bellal et al. [50] evaluated the $\mathrm{H}_{2}$ production by $\mathrm{SrSnO}_{3}$ combined with $\mathrm{CuFeO}_{2}$ under UV light. $\mathrm{SrSnO}_{3}$ showed a dislocation of the conduction band to bigger wavelength after combination with $\mathrm{CuFeO}_{2}$. The authors observed that there is a shift of the conduction band edge of $\mathrm{SrSnO}_{3}$ to the longer wavelength when the oxide was combined with $\mathrm{CuFeO}_{2}$. Thus, the $\mathrm{SrSnO}_{3} / \mathrm{CuFeO}_{2}$ system has a conduction band below the $\mathrm{H}_{2} \mathrm{O} / \mathrm{H}_{2}$ level, inducing photodegradation of $\mathrm{H}_{2} \mathrm{O}$ for $\mathrm{H}_{2}$ production under visible light irradiation. A theoretical and experimental evaluation of the optical properties, photoluminesce and band gap of $\mathrm{SrSnO}_{3}$ were done in [46] using DFT with evaluation of the material for the $\mathrm{H}_{2}$ production. An intrinsic emission was observed due to a band-to-band absorption, with no influence of defects and impurities. For $\mathrm{H}_{2}$ production under $\mathrm{UV}$ light, $\mathrm{RuO}_{2}$ was used as co-catalyst. The photocatalytic activity was assigned to the $\mathrm{SnO}_{6}$ distortion besides the strong interaction among electrons and $\mathrm{SrSnO}_{3}$ lattice.

Dye photodegradation: stannates with perovskite structure have been used in the photocatalytic degradation of organic compounds, especially of textile dyes (Table V). A comparison of the photocatalytic degradation of methyl orange by the three different stannates under UV light was done by Wang et al. [56], who synthesized the materials by the hydrothermal method using conventional heating $(\mathrm{CH})$ or microwave heating (MH). The following photocatalytic conversion was obtained: $\mathrm{CaSnO}_{3}$ (94\% for $\mathrm{MH}, 72 \%$ for $\mathrm{CH})>\mathrm{SrSnO}_{3}(84 \% \mathrm{MH}, 60 \% \mathrm{CH})>\mathrm{BaSnO}_{3}(27 \% \mathrm{MH}$, $19 \% \mathrm{CH})$. These results indicated that different factors determine the photocatalytic activity: i) surface area and band gap; ii) distortion and octahedra tilting due to the ionic radius of the A cation; iii) crystalline structure of the stannates. The highest activity of $\mathrm{CaSnO}_{3}$ was assigned to the highest structure distortion, in agreement to the previous data on $\mathrm{H}_{2}$ production. Differently from the $\mathrm{H}_{2}$ production, more papers about dye photodegradation by $\mathrm{CaSnO}_{3}$ have been published by different research groups, all of them without doping or co-catalysts. Meng et al. [59] synthesized $\mathrm{CaSn}(\mathrm{OH})_{6}$ microcubes using the sonochemical method and observed a high activity for the photodegradation of benzene

Table IV - Stannates applied in the $\mathrm{H}_{2}$ generation.

[Tabela IV - Estanatos aplicados na geração de $H_{2}$.]

\begin{tabular}{cccc}
\hline Photocatalyst & Measure & Reaction condition & Ref. \\
\hline $\mathrm{SrSnO}_{3}$ & $\mathrm{H}_{2}$ generation & Reactor quartz; closed gas circulation system 450 W Hg lamp & {$[15]$} \\
$\mathrm{CaSnO}_{3}, \mathrm{BaSnO}_{3}$ & $\mathrm{H}_{2} / \mathrm{O}_{2}$ generation & Quartz cell; closed gas circulation system - 400 W Hg lamp & {$[36]$} \\
$\mathrm{SrSnO}_{3}$ & & Container of quartz; closed gas circulation system - 125 W & [43] \\
$\mathrm{CaSnO}_{3}, \mathrm{BaSnO}_{3}$ & $\mathrm{H}_{2}$ generation & Hg lamp & \\
$\mathrm{SrSnO}_{3}$ & $\mathrm{H}_{2} / \mathrm{O}_{2}$ generation & Quartz cell; closed gas circulation system - 400 W Hg lamp & {$[44]$} \\
$\mathrm{SrSnO}_{3}$ & $\mathrm{H}_{2}$ generation & Quartz cell; closed gas circulation system - 400 W Hg lamp & {$[45]$} \\
$\mathrm{BaSnO}_{3}$ & $\mathrm{H}_{2} / \mathrm{O}_{2}$ generation & Quartz cell; closed gas circulation system - 400 W Hg lamp & {$[46]$} \\
$\mathrm{SrSnO}_{3}$ & Pyrex reactor; closed gas circulation system - three 200 W- W & {$[50]$} \\
$\mathrm{SrSnO}_{3} \mathrm{SrSnO}_{3} /$ & $\mathrm{H}_{2} / \mathrm{O}_{2}$ generation & lamps & \\
$\mathrm{CuFeO}_{2}$ & $\mathrm{H}_{2}$ generation & Closed gas circulation system - 300 W Xe lamp & {$[51]$} \\
$\mathrm{BaSnO}_{3}$ & $\mathrm{H}_{2}$ generation & Reactor quartz; closed gas circulation system 700 W Hg lamp & [52] \\
$\mathrm{SrSnO}_{3}$ & & &
\end{tabular}


and methyl orange under UV light. The performance of the hydroxide in the photodegradation of benzene was better than the $\mathrm{TiO}_{2}$ (P25, Degussa) one, with a higher durability. A degradation mechanism was proposed by the authors. $\mathrm{CaSnO}_{3}$ was also used for the photodegradation of azo-dyes [60, 61]. For instance, Moshtaghi et al. [61] synthesized $\mathrm{CaSnO}_{3}$ nanocubes by co-precipitation and showed a good activity for the degradation of acid brown-14 (77\%) and acid blue-92 (67\%). Lucena et al. [60] synthesized $\mathrm{CaSnO}_{3}$ by the modified-Pechini method and evaluated the photodegradation of the remazol golden yellow (RNL) under UV light at different $\mathrm{pH}$ values. The activity was higher at pH $3(51 \%)$ than $\mathrm{pH} 6(34 \%)$, which was correlated to the highest adsorption, $16 \%$ at $\mathrm{pH} 3$ and $8 \%$ at $\mathrm{pH} 6$.

Two other papers were found reporting the use of $\mathrm{CaSnO}_{3}$ on the photodegradation of dyes $[71,86]$, which were not identified during our search on the available databases (Web of Science, Scopus and Scielo), but are in the scope of this review. In the first paper, Wang et al. [71] used the $\mathrm{CaSn}(\mathrm{OH})_{6}$ precursor obtained by the hydrothermal method with conventional heating to synthesize $\mathrm{CaSnO}_{3}$ microcubes at different temperatures $\left(500,600,700\right.$ and $800{ }^{\circ} \mathrm{C}$ ) and evaluate its efficiency in the photocatalytic degradation of methyl orange. In spite of the high activity showed by all samples, the following activity order was identified for the different heat treatment temperature: $800>700>600$ ${ }^{\circ} \mathrm{C}$. The sample heat-treated at $800{ }^{\circ} \mathrm{C}$ was evaluated in the photodegradation of other organic compounds as salicylic acid, 44-hydroxyazobenzene, 4-chlorophenol and rhodamine B. A conversion of $99 \%$ was achieved for rhodamine B after 60 min of irradiation, while $97 \%$ was obtained for the other pollutants after $120 \mathrm{~min}$. According to these results, $\mathrm{CaSnO}_{3}$ is a promising material for organic pollutant degradation.
For the last paper, only the abstract was available because it is a Chinese paper. Wang et al. [86] synthesized $\mathrm{CaSnO}_{3}$ by co-precipitation and obtained $94 \%$ of degradation for methylene blue after $100 \mathrm{~min}$ of irradiation.

$\mathrm{SrSnO}_{3}$ was evaluated for dye degradation in the pure form [16, 55], doped with nitrogen [53] and combined with $\mathrm{Ag}$ as co-catalyst [57]. Concerning the pure material, $\mathrm{SrSnO}_{3}$ was synthesized by the hydrothermal [16] and coprecipitation [55] methods. Junploy et al. [16] used rod-like $\mathrm{SrSnO}_{3}$ for the degradation of methylene blue under UV irradiation and obtained a discoloration amount of $85 \%$ after $320 \mathrm{~min}$. Moshtaghi et al. [55] evaluated the degradation of two different azo dyes (acid blue-92 and acid black 1) using UV or visible irradiation. For the acid-blue dye, discolorations of $52 \%$ and $93 \%$ were obtained after 120 min under visible light and UV irradiation, respectively, while $62 \%$ and $96 \%$ of degradation were obtained for the acid black dye after 90 min under visible light and UV irradiation, respectively. One more paper was published [87], but only abstract was available, as it is a Chinese paper. This paper was not obtained during our search process. The authors synthesized $\mathrm{SrSnO}_{3}$ by the hydrothermal method and evaluated the photodecomposition of rhodamine B, methylene blue and orange II under visible light. According to the authors, $100 \%$ of rhodamine was degraded after 6 h, $96 \%$ of methylene blue after $3 \mathrm{~h}$ and $93 \%$ of orange II after $3.5 \mathrm{~h}$. Due to its band gap, the photocatalytic activity of $\mathrm{SrSnO}_{3}$ under visible light is usually low, which can be improved by doping procedures. For instance, Lobo et al. [53] synthesized $\mathrm{SrSnO}_{3}$ by solid state reaction followed by its nitridation by ammonolysis. Three different nitridation temperatures were used $\left(600,650\right.$ and $\left.750{ }^{\circ} \mathrm{C}\right)$; the highest temperature led to the stannate decomposition, while better

Table V - Stannates applied to the degradation of textile dyes.

[Tabela $V$ - Estanatos aplicados na degradação de corantes têxteis.]

\begin{tabular}{|c|c|c|c|}
\hline Photocatalyst & Dye & Reaction condition & Ref. \\
\hline $\mathrm{SrSnO}_{3}$ & Methylene blue & Two 18W UV lamps & {$[16]$} \\
\hline $\mathrm{BaSnO}_{3}$ & Erythrosine & UV irradiation in quartz reactor - $400 \mathrm{~W} \mathrm{Hg}$ lamp & [41] \\
\hline $\mathrm{BaSnO}_{3}$ & Eriochrome black T & UV irradiation in quartz reactor - $400 \mathrm{~W} \mathrm{Hg}$ lamp & [42] \\
\hline $\mathrm{SrSnO}_{3}: \mathrm{N}$ & Methylene blue & $\begin{array}{l}\text { Reactor (batch) and UV and visible lamps (120 W - Hg) } \\
\text { and (100 W - W) }\end{array}$ & {$[53]$} \\
\hline $\mathrm{Ba}_{1-\mathrm{x}} \mathrm{Sr}_{\mathrm{x}} \mathrm{SnO}_{3}$ & Remazol golden yellow & Petri plate and UVC lamp of $\lambda=254 \mathrm{~nm}$ & {$[54]$} \\
\hline $\mathrm{SrSnO}_{3}$ & Acid blue- 92 acid black-1 & $\begin{array}{c}\text { Reactor glass and UV and visible lamps (Osram Ultra- } \\
\text { Vitalux } 300 \mathrm{~W} \text { ) }\end{array}$ & {$[55]$} \\
\hline $\begin{array}{l}\mathrm{CaSnO}_{3}, \mathrm{BaSnO}_{3} \\
\mathrm{SrSnO}_{3}\end{array}$ & Methyl orange & $\begin{array}{c}\text { Reactor (tube) quartz with } 3 \text { lamps of } 4 \mathrm{~W} \text { - Philips, } \\
\text { TUV4W / G4 T5 }\end{array}$ & {$[56]$} \\
\hline $\mathrm{Ag} / \mathrm{SrSnO}_{3}$ & Methylene blue & Two UV lamps - $15 \mathrm{~W}$ & [57] \\
\hline $\mathrm{BaSn}_{1-\mathrm{x}} \mathrm{Fe}_{\mathrm{x}} \mathrm{O}_{3}$ & Remazol golden yellow & Irradiation of UVC lamp (0.5-1.0 mW) mod. ZG-30T8 & [58] \\
\hline $\mathrm{CaSn}(\mathrm{OH})_{6}$ & Methyl orange & UV irradiation & [59] \\
\hline $\mathrm{CaSnO}_{3}$ & Remazol golden yellow & Petri plate and UVC lamp of $\lambda=254 \mathrm{~nm}$ & {$[60]$} \\
\hline $\mathrm{CaSnO}_{3}$ & $\begin{array}{l}\text { Acid blue- } 92 \text { acid } \\
\text { brown- } 14\end{array}$ & $\begin{array}{l}\text { Reactor glass and UV and visible lamps (Osram Ultra- } \\
\text { Vitalux } 300 \mathrm{~W} \text { ) }\end{array}$ & [61] \\
\hline
\end{tabular}


results were obtained at 600 and $650{ }^{\circ} \mathrm{C}$. The photocatalytic discoloration of methylene blue was evaluated under UV irradiation $(254 \mathrm{~nm})$ and under visible light and the results were compared to the performance of $\mathrm{TiO}_{2}$ ( $\mathrm{P} 25$, Evonik), evaluated in the same conditions. Under UV irradiation, the efficiency of the nitrided samples was $30 \%$ higher than the non-nitrided one, while a much higher difference was found under visible radiation. Under this condition, the activity of the nitrided sample was 4-fold the activity of non-nitrided one and 2-fold the activity of $\mathrm{TiO}_{2}$. In spite of this meaningful difference, an only insignificant variation of the band gap was measured after nitridation, because it is a surface process and only small changes were observed in the $\mathrm{SrSnO}_{3}$ structure. Otherwise, as photocatalysis is a surface process, this superficial nitridation is sufficient to promote the increase of the material performance. The use of $\mathrm{Ag}$ as cocatalyst was evaluated by Junploy et al. [57], who reported a meaningful increase in the photocatalytic degradation of methylene blue under UV light after incorporation of $5 \mathrm{wt} \%$ of $\mathrm{Ag}$ on the $\mathrm{SrSnO}_{3}$ surface. An increase in degradation from $85 \%$ to $99.5 \%$ after 320 min was reported.

Barium stannate was tested as a photocatalyst for dye degradation in pure $[54,58]$ and in the doped form [41, 42]. Moshtagi et al. [42] obtained nanostructured $\mathrm{BaSnO}_{3}$ by co-precipitation and evaluated the influence of the synthesis parameters in the morphology of the particles in order to obtain nanostructures. The nanometric material was evaluated in the photocatalytic degradation of the anionic dye eriochrome black T and obtained $84 \%$ of degradation after $120 \mathrm{~min}$ of UV irradiation. Moshtaghi et al. [41] also evaluated the erythrosine dye by $\mathrm{BaSnO}_{3}$ under UV irradiation and obtained $82 \%$ of photodegradation after $120 \mathrm{~min}$. According to these results, the $\mathrm{BaSnO}_{3}$ activity may be improved by the use of nanomaterials. Doped $\mathrm{BaSnO}_{3}$ was tested in the photodegradation of the RNL azo-dye in two different papers from the same research group. Moura et al. [58] synthesized the $\mathrm{BaSn}_{1-x} \mathrm{Fe}_{x} \mathrm{O}_{3}$ $(x=0.05$ and 0.10$)$ by the modified Pechini method and performed the photocatalytic tests under UVC irradiation. The photocatalytic efficiency at $\mathrm{pH} 3(93 \%)$ was higher than degradation at $\mathrm{pH} 6$ for the sample $\mathrm{BaSn}_{0.9} \mathrm{Fe}_{0.1} \mathrm{O}_{3}$. Only $7 \%$ of adsorption was obtained at $\mathrm{pH} \mathrm{3}$, which suggests that an indirect degradation mechanism takes place during photocatalysis. The dye color was reduced to half after $1 \mathrm{~h}$ of irradiation for the sample $\mathrm{BaSn}_{0.9} \mathrm{Fe}_{0.1} \mathrm{O}_{3}$, which is higher than the undoped material. The improvement of the activity is directly related to the doping process, probably due to the formation of intermediate levels inside the band gap, which may trap electrons avoiding electron-hole recombination. Sales et al. [54] synthesized $\mathrm{Ba}_{1-x} \mathrm{Sr}_{x} \mathrm{SnO}_{3}(\mathrm{x}=0,0.25,0.50$, $0.75,1)$ particles by solid-state reaction. Formation of the perovskite structure was influenced by the $\mathrm{Sr}^{2+}$ addition, which also changed the band gap values, which are smaller for higher $\mathrm{Ba}^{2+}$ contents. Differently from other results comparing the $\mathrm{ASnO}_{3}$ perovskites, $\mathrm{BaSnO}_{3}$ presented double efficiency of $\mathrm{SrSnO}_{3}$. According to adsorption tests, a much smaller adsorption of RNL takes place on $\mathrm{SrSnO}_{3}$ than on
$\mathrm{BaSnO}_{3}$, which is 3 -fold higher. A comparison between the photocatalytic discoloration and the discoloration due to adsorption indicated an increase from $47 \%$ to $74 \%$ for $\mathrm{BaSnO}_{3}$ and an increase from $14 \%$ to $38 \%$ for $\mathrm{SrSnO}_{3}$. This result indicates that an indirect mechanism takes place when $\mathrm{SrSnO}_{3}$ is used as a photocatalyst, while a direct mechanism may take place in the presence of $\mathrm{BaSnO}_{3}$, as this material produces fewer hydroxyl radicals, as demonstrated in [54].

\section{FINAL REMARKS}

The research data indicated a relatively small number of papers on stannates applied as a photocatalyst, in spite of the promising activities showed in the degradation of organic compounds. Evaluation of the patents showed researches concerning structural, textural and morphological modifications of the stannates, but none of them indicated the use of stannates as photocatalysts. A careful analysis of the papers indicated that papers concerning on photodegradation of textile dyes make less association between crystalline structure, band structure and presence of co-catalysts than papers about $\mathrm{H}_{2}$ production. Some papers only report the activity, which may not be compared to other papers, as most reactors are lab made besides the use of lamps with different powers and emissions in different regions. This information indicated the need to deepen the knowledge in this area, by performing more on post-catalysis researches in order to identify the reaction by-products and also evaluate the possibility of complete mineralization of the dyes, confirming the sustainable application for environmental remediation. Moreover, few papers concern the use of dopants, which could be more explored. Another important conclusion is the highest efficiency of $\mathrm{CaSnO}_{3}$ in all of the papers that compared the performance of $\mathrm{CaSnO}_{3}, \mathrm{SrSnO}_{3}$ and $\mathrm{BaSnO}_{3}$. This behavior was correlated to the presence of distorted octahedra, which changes the band structure and the charge migration.

\section{ACKNOWLEDGEMENTS}

This work was supported by CAPES/MEC, CNPq/ MCTIC, PROINFRA/FINEP/MCTIC, UFPB and UFPI.

\section{REFERENCES}

[1] E. Brillas, C.A. Martínez-Huilte, Appl. Catal. B Environ. 166 (2015) 603.

[2] Conama, Res. 430/2011, DOU 92 (2014).

[3] K.S.D. Araújo, R. Antonelli, B. Gaydeczka, A.C. Granato, G.R.P. Malpass, Rev. Amb. Água 11 (2016) 387.

[4] B. Bethi, S.H. Sonawane, B.A. Bhanvase, S.P. Gumfekar, Chem. Eng. Process. Process Intensif. 109 (2016) 178.

[5] A.R. Ribeiro, O.C. Nunes, M.F.R. Pereira, A.M. Silva, Environ. Int.75 (2015) 33.

[6] A. Babuponnusami, K. Muthukumar, J. Environ. Chem.

Eng. 2 (2014) 557.

[7] F.C. Moreira, R.A.R. Boaventura, E. Brillas, V.J. Vilar, 
Appl. Catal. B Environ. 202 (2017) 217.

[8] M. Cheng, G. Zeng, D. Huang, C. Lai, P. Xu, C. Zhang, Y. Liu, Chem. Eng. J. 284 (2016) 582.

[9] M. Ghiasi, A. Malekzadeh, Sep. Purif. Technol. 134 (2014) 12.

[10] J. Ângelo, L. Andrade, L.M. Madeira, A. Mendes, J. Environ. Manage. 129 (2013) 522.

[11] A.M. Azad, T.Y. Pang, M.A. Alim, Act. Passiv. Electron . Components 26 (2003) 151.

[12] Y. Li, H. Zhang, B. Guo, M. Wei, Electrochim. Acta. 70 (2012) 313.

[13] H. Cheng, Z. Lu, Solid State Sci. 10 (2008) 1042.

[14] X. Hu, Y. Tang, T. Xiao, J. Jiang, Z. Jia, D. Li, L. Luo, J. Phys. Chem. C 114 (2010) 947.

[15] C.W. Lee, D.W. Kim, I.S. Cho, S. Park, S.S. Shin, S.W. Seo, K.S. Hong, Int. J. Hydrogen Energy 37 (2012) 10557.

[16] P. Junploy, S. Thongtem, T. Thongtem, Superlattices Microstruct. 57 (2013) 1.

[17] US Geological Survey, "Mineral commodity study 2018" (2018).

[18] Lei 9.279, 14/05/1996, "Regula direitos e obrigações" (1996).

[19] X.L. Pang, C.H. Jia, G.Q. Li, W.F. Zhang, Opt. Mater. 34 (2011) 234.

[20] T.M. Duarte, P.G.C. Buzolin, I.M.G. Santos, E. Longo, J.R. Sambrano, Theor. Chem. Acc. 135 (2016) 151.

[21] S.S. Shin, E.J. Yeom, W.S. Yang, S. Hur, M.G. Kim, J. Im, S.I. Seok, Science 356 (2017) 167.

[22] M. Mackevičius, F. Ivanauskas, A. Kareiva, V. Mackevičius, A. Stanulis, J. Math. Chem. 53 (2015) 1227.

[23] A.A. Kumar, A. Kumar, J.K. Quamara, G.R. Dillip, S.W. Joo, J. Kumar, RSC Adv. 5 (2015) 17202.

[24] J. Bohnemann, R. Libanori, M.L. Moreira, E. Longo, Chem. Eng. J. 155 (2009) 905.

[25] A.V. Mudring, T. Alammar, I. Slowing, J. Anderegg, ChemSusChem (2017) 3387.

[26] A. Stanulis, A. Katelnikovas, M.V. Bael, A. Hardy A. Kareiva, T. Justel, J. Lumin. 172 (2016) 323.

[27] H. Chen, N. Umezawa, Int. J. Photoenergy 2014 (2014) 1.

[28] A. Stanulis, S. Sakirzanovas, M.V. Bael, A. Kareiva, J. Sol-Gel Sci. Technol. 64 (2012) 643.

[29] Z. Zhang, X. Li, C. Gao, F. Teng, Y. Wang, L. Chen, E. Xie, J. Mater. Chem. A 3 (2015) 12769.

[30] J. Ahmed, C.K. Blakely, S.R Bruno, V.V. Poltavets, Mater. Res. Bull. 47 (2012) 2282.

[31] E. Gul, A. Stanulis, Y. Barushka, E. Garskaite, R. Ramanauskas, A.U. Morkan, A. Kareiva, J. Mater. Sci. 52 (2017) 12624.

[32] P.H. Borse, J.S. Lee, H.G. Kim, J. Appl. Phys. 100 (2006) 5.

[33] A. Kumar, V. Sahrawat, A.A. Kumar, S. Priya, Trans. Indian Inst. Met. 70 (2017) 573.

[34] X. Pang, Y. Zhang, L. Ding, Z. Su, W.F. Zhang, J. Nanosci. Nanotechnol. 10 (2010) 1860.

[35] S.M.D. Oliveira, Diss. Mestr., Un. Fed. Uberlândia (2015).
[36] W. Zhang, J. Tang, J. Ye, J. Mater. Res. 22 (2007) 1859.

[37] G.G.C. Lima, C.A.P Lima, F.F. Vieira, E.M. Silva, Rev. Eletr. Mater. Process. 9 (2014) 22.

[38] S.K. Sen, S. Raut, P. Bandyopadhyay, S. Raut, Fungal Biol. Rev. 30 (2016) 112.

[39] S.P. Oliveira, W.L.L. Silva, R.R. Viana, Cerâmica 59, 350 (2013) 338.

[40] P.A. Poggere, R. Davis, S.F. Montanher, V.D.S. Lobo, in: Enc. Divulg. Cient. Tecn. (2011) 2176.

[41] S. Moshtaghi, S. Zinatloo-Ajabshir, J. Mater. Sci. Mater. Electron. 27 (2016) 834.

[42] S. Moshtaghi, S. Zinatloo-Ajabshir, J. Mater. Sci. Mater. Electron. 27 (2016) 425.

[43] F. Zhong, H. Zhuang, Q. Gu, J. Long, RSC Adv. 6 (2016) 42474.

[44] D. Chen, J. Ye, Chem. Mater. 19 (2007) 4585.

[45] Y. Yuan, J. Lv, X. Jiang, Z. Li, T. Yu, Z. Zou, J. Ye, Appl. Phys. Lett. 91 (2007) 27.

[46] W.F. Zhang, J. Tang, J. Ye, Chem. Phys. Lett. 418 (2006) 174.

[47] J. Xing, Y.H. Li, H.B. Jiang, Y. Wang, H.G. Yang, Int. J. Hydrogen Energy 39 (2014) 1237.

[48] M. Ikeguchi, T. Mimura, Y. Sekine, E. Kikuchi, M. Matasukata, Appl. Catal. A Gen. 290 (2005) 212.

[49] A.G. Santos, I.K.F. Costa, F.K.G. Santos, C.P. Souza, Holos 3 (2015) 30.

[50] B. Bellal, B. Hadjarab, A. Bouguelia, M. Trari, Theoret. Exp. Chem. 45 (2009) 172.

[51] P.H. Borse, U.A. Joshi, S.M. Ji, J.S. Jang, J.S Lee, E.D. Jeong, H.G. Kim, Appl. Phys. Lett. 90 (2007) 34103.

[52] T. Alammar, I. Hamm, V. Grasmik, M. Wark, A.V. Mudring, Inorg. Chem. 56 (2017) 6920.

[53] T.M. Lobo, R. Lebullenger, V. Bouquet, M. Guillouxviry, I.M.G. Santos, I.T. Weber, J. Alloys Compd. 649 (2015) 491.

[54] H.B. Sales, V. Bouquet, S. Députier, S. Ollivier, F. Gouttefangeas, M. Guilloux-viry, I.M.G. Santos, Sol. State Sci. 28 (2014) 67.

[55] S. Moshtaghi, S. Gholamrezaei, M.S. Niasari, P. Mehdizadeh, J. Mater. Sci. Mater. Electron. 27 (2016) 414.

[56] W. Wang, S. Liang, K. Ding, J. Bi, C.Y. Jimmy, P.K. Wong, L. Wu, J. Mater. Sci. 49 (2014) 1893.

[57] P. Junploy, T. Thongtem, S. Thongtem, A. Phuruangrat, J. Nanomater. 2014 (2014) 261395.

[58] K.F. Moura, L. Chantelle, D. Rosendo, E. Longo, I.M.G. dos Santos, Mater. Res. 20, Suppl. 2 (2017) 317.

[59] S. Meng, D. Li, M. Sun, W. Li, J. Wang, J. Chen, G. Xiao, Catal. Commun. 12 (2011) 972.

[60] G.L. Lucena, L.C. de Lima, L.M.C. Honório, A.L.M. de Oliveira, R.L. Tranquilim, E. Longo, A.G. de Souza, I.M.G. dos Santos, Cerâmica 63, 368 (2017) 536.

[61] S. Moshtaghi, S. Gholamrezaei, M.S. Niasari, J. Mol. Struct. 1134 (2017) 511.

[62] C.C.L. Santos, Tese Dr., Un. Fed. Paraíba (2013).

[63] W. Li, Y. Zhao, S. Yuan, L. Shi, Z. Wang, J. Fang, M. Zhang, J. Mater. Sci. 47 (2012) 7999.

[64] H. Santos, C.S. Ludmila de Paula, F.B. Passos, Rev. 
Virt. Quím. 7 (2015) 1441.

[65] A.M. Pena, J.L.G, Fierro, Chem. Rev. 101 (2011) 1981. [66] E. Grabowska, Appl. Catal. B Environ. 186 (2016) 97.

[67] A. Loken, Dept. Chem., Un. Oslo, Noruega, 2011.

[68] E.H. Mountstevens, J.P. Attfield, S.A.T. Redfern, J. Phys. Condens. Matter. 15 (2003) 8315.

[69] M.R. Cassia-Santos, S.B. Mendes, M.F.C. Gurgel, A.T. Figueiredo, M. Godinho Jr., C.E.M. Braz, E. Longo, Cerâmica 60, 354 (2014) 259.

[70] J. Maul, I.M.G. Santos, J.R. Sambrano, A. Erba, Theor. Chem. Acc. 135 (2016) 36.

[71] W. Wang, J. Bi, L. Wu, Z. Li, X. Fu, Scripta Mater. 60 (2009) 186.

[72] M.C.F. Alves, S.C. Souza, M.R.S. Silva, E.C. Paris, S.J.G. Lima, R.M. Gomes, E. Longo, A.G. De Souza, I.M. Garcia Dos Santos, J. Therm. Anal. Calorim. 97 (2009) 179. [73] H. Mizoguchi, H.W. Eng, P.M. Woodward, Inorg. Chem. 43 (2004) 1667.

[74] S. Ahmed, M.G. Rasul, R. Brown, M.A. Hashib, J. Envir. Manage. 92 (2011) 311.

[75] S. Chowdhury, R. Balasubramanian, Appl. Catal. B Environ. 160 (2014) 307.

[76] M. Yasmina, K. Mourad, S.H. Mohammed, C. Khaoula,
Ener. Procedia 50 (2014) 559.

[77] C. Byrne, G. Subramanian, S.C. Pillai, J. Envir. Chem. Eng. 6 (2018) 3531.

[78] K. Kabra, R. Chaudhary, R.L. Sawhney, Ind. Eng. Chem. Res. 43 (2004) 7683.

[79] M.A. Rauf, S.S. Ashraf, Chem. Eng. J. 151 (2009) 10. [80] N. Serpone, A.V. Emelie, Int. J. Photoenergy 4 (2002) 91.

[81] A. Ajmal, I. Majeed, R.N. Malik, H. Idriss, M.A. Nadeem, RSC Adv. 4 (2014) 37003.

[82] J. Sato, H. Kobayashi, Y. Inoue, J. Phys. Chem. B 107 (2003) 7970.

[83] H.W. Eng, P.W. Barnes, B.M. Auer, P.M. Woodward, J. Solid State Chem. 175 (2003) 94.

[84] B. Hadjarab, M. Trari, M. Kebir, Mater. Sci. Semicond. Process. 29 (2015) 283.

[85] E. Moreira, J.M. Henriques, D.L. Azevedo, E.W.S. Caetano, V.N. Freire, E.L. Albuquerque, J. Solid State Chem. 187 (2012) 186.

[86] H. Wang, G.H. Zhu, Q.L. Liang, S.P. Guo, S.M. Yang, J. Synth. Crystals 4 (2013) 45.

[87] Q. Huang, H. Xiao, X. Zhang, S. Lin, J. Funct. Mater. 2 (2016) 43.

(Rec. 13/04/2018, Ac. 19/05/2018) 